\title{
Importance of Diagnostic Waxing in Oral Rehabilitation: Case Report
}

\section{Importância do Enceramento Diagnóstico na Reabilitação Oral: Relato de Caso}

\author{
Mariana Lima da Costa Valente ${ }^{\mathrm{a}}$; Marcela Silva Costa ${ }^{\mathrm{b}}$; Paulo Marcos Bérgamo ; Denise Tornavoi de Castro*d
}

\author{
aSão Paulo University, Ribeirão Preto School of Dentistry, Department of Dental Materials and Prothesis. SP, Brazil. \\ ${ }^{b}$ University of Uberaba, Department of Biomaterials, MG, Brazil. \\ 'São Paulo University, Ribeirão Preto School of Dentistry, SP, Brazil. \\ ${ }^{d}$ Uberaba University, Department of Biomaterials, Stricto Sensu Post-Graduate Program in Dentistry. MG, Brasil. \\ *E-mail: dctornavoi@hotmail.com \\ Recebido em: 10/02/2020 \\ Aprovado em: 03/06/2020
}

\begin{abstract}
Currently, aesthetics, and especially the smile, adds considerable social value. In this way, patients suffering from dental loss wish that their rehabilitation be performed quickly and safely. The aim of oral rehabilitation is to restore masticatory, phonetic, aesthetic and quality of life to the patient. The diagnostic step is one of the most important and relevant steps in establishing a correct treatment plan and, in this way, it is possible to obtain excellent results. The present study aimed to demonstrate the importance of diagnostic waxing in oral rehabilitation. Patient sought treatment at the Dental Prosthesis Specialization Course at Odonto School, due to complaints associated with aesthetics and function. To improve their quality of life, planning of case was carried out through diagnostic waxing and a prosthetic solution was proposed. At the end of treatment and during the follow-up of the case, the patient reported satisfaction and significant improvement in quality of life. It can be concluded that the diagnostic waxing presents customized solutions offering, through a previous study, an effective clinical resolution to the patient.
\end{abstract} Keywords: Mouth Rehabilitation. Dental Restoration, Temporary. Dental Restoration, Temporary.

\section{Resumo}

Atualmente, a estética, e em especial o sorriso, agregam um valor social considerável. Dessa forma, ao sofrerem a perda dental, os pacientes desejam que sua reabilitação seja realizada de forma rápida e segura. A reabilitação oral tem como objetivo devolver ao paciente a eficiência mastigatória, fonética, estética e a qualidade de vida. A etapa diagnóstica constitui um dos passos mais importantes e relevantes no estabelecimento de um correto planejamento do tratamento e, desta forma, torna-se possível obter resultados de excelência. O presente estudo teve como objetivo demonstrar a importância do enceramento diagnóstico na reabilitação oral. Paciente procurou tratamento no Curso de Especialização em Prótese Dentária da Odonto School, devido a queixas associadas a estética e função. Para melhorar sua qualidade de vida, foi realizado o planejamento do caso por meio do enceramento diagnóstico e uma solução protética foi proposta. Ao final do tratamento e durante o acompanhamento do caso, a paciente relatou satisfação e melhora significativa na qualidade de vida. Pode-se concluir que o enceramento diagnóstico apresenta soluções personalizadas oferecendo, por meio de estudo prévio, uma resolução clínica efetiva ao paciente.

Palavras-chave: Reabilitação Bucal. Restauração Dentária Temporária. Prótese Dentária Temporária.

\section{Introduction}

In contemporary society, the search for patterns of beauty and the overvaluation of self-image reflect in the various areas of health, including Dentistry . Patients want a beautiful smile, with white and aligned teeth and healthy gums and dentists should respond and follow these new challenges ${ }^{2,3}$.

An undesirable esthetic of dental elements that impair the harmony of the smile, associated with the lack of oral health, reflects in self-esteem and consequently in the social aspects in which the individual enters, triggering feelings of dissatisfaction, insecurity, personal and social nonacceptance and lack of self-confidence . Thus, the integrated dental treatment should involve the restoration of the oral environment, providing health, esthetics and function.

For this objective to be achieved, there must be an understanding of the patient's needs and effective communication between the team. Patient involvement in the decision-making process regarding the treatment plan is essential, and professionals must understand the desires and expectations, just as the patient must recognize the limitations of his or her case ${ }^{6,7}$.

The treatment plan in dentistry must necessarily integrate and adapt clinical concepts to the personality and conception of what is esthetic to the patient, but this connection is often difficult, that is, it is not easy to explain to the patient the perspective of the professional, just as it is difficult for the patient to aim for what it is "beautiful" for him or her. ${ }^{2}$

Previewing the final treatment result is essential for a predictable restorative procedure, and diagnostic waxing (DW) is an important tool ${ }^{8,9}$.

By means of a study model, DW enables dental wax reproduction, providing analysis of the anatomical teeth shape 
to be restored, visualization of the preparation to be performed and demonstration to the patient of the final result, ensuring maximum predictability, being the first contact of the patient with the proposed treatment ${ }^{10}$. In addition, DW makes it possible to predict occlusal stability, freedom of mandibular movements and the absence of interference, which, in turn, are essential for the balance of the stomatognathic apparatus ${ }^{3}$.

The technique of diagnostic closure has also been used in the implantation of dentistry, providing the possible sites for the installation of implants, as well as defining the location, direction and inclination, the alignment and relationship with the remaining teeth, facilitating the work of the laboratory technician in the manufacturing, and the prosthetic, in the installation of the prosthesis ${ }^{9}$. Therefore, the present study aimed to demonstrate a clinical case, demonstrating the importance of diagnostic closure in oral rehabilitation.

\section{Development}

\subsection{Case Report}

M.J.R., a 54-year-old female patient, low socioeconomic condition and poor oral hygiene, sought the OdontoSchool clinic with a complaint associated with the smile esthetics, phonation and chewing. Patient reports "the space in the front teeth will not let me smile" (Figure 1).

Figure 1 - Initial photos of the case: A. Without inferior removable partial prosthesis; B. with inferior removable partial prosthesis

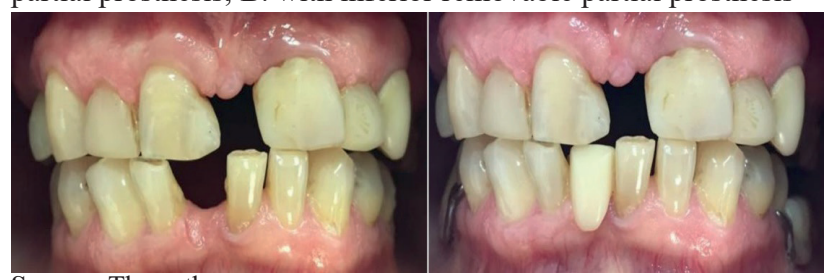

Source: The authors.

During the patient's anamnesis, she reported a health problem related to a stroke 25 years ago. Clinically, dental absences were identified in the lower arch, of the elements $36,37,41,46$ and 47, and in the upper arch of the elements 14, 16,17 and 24, and extensive restorations in composite resin in the anterior teeth. The patient had been used a removable partial lower prosthesis for 20 years. Radiographic examination revealed bone volume in the jaw and bone loss in the maxilla, endodontic treatment and extensive coronary destruction of the element 26 (Figure 2).

Figure 2 - Panoramic X-ray.

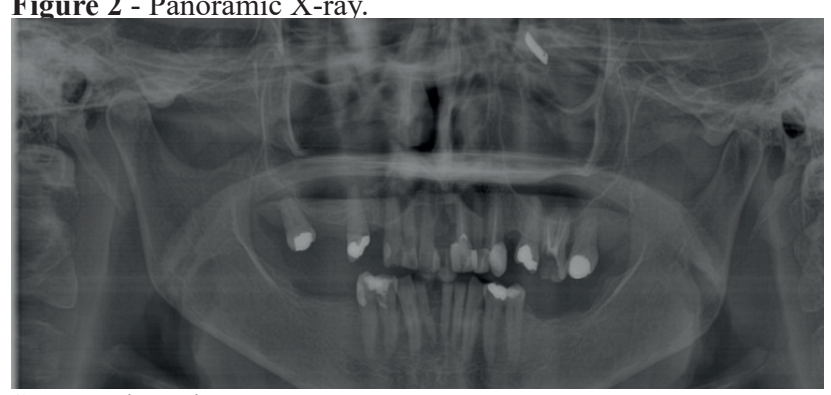

Source: The authors.
For the planning of this rehabilitation, the upper and lower arcades of the patient were initially molded, with alginate (irreversible hydrocolloid material), in order to obtain the study models. The assembly was carried out with a semiadjustable articulator (ASA) in a centric relation and after a case study, the progressive diagnostic closure technique was employed (Figure 3).

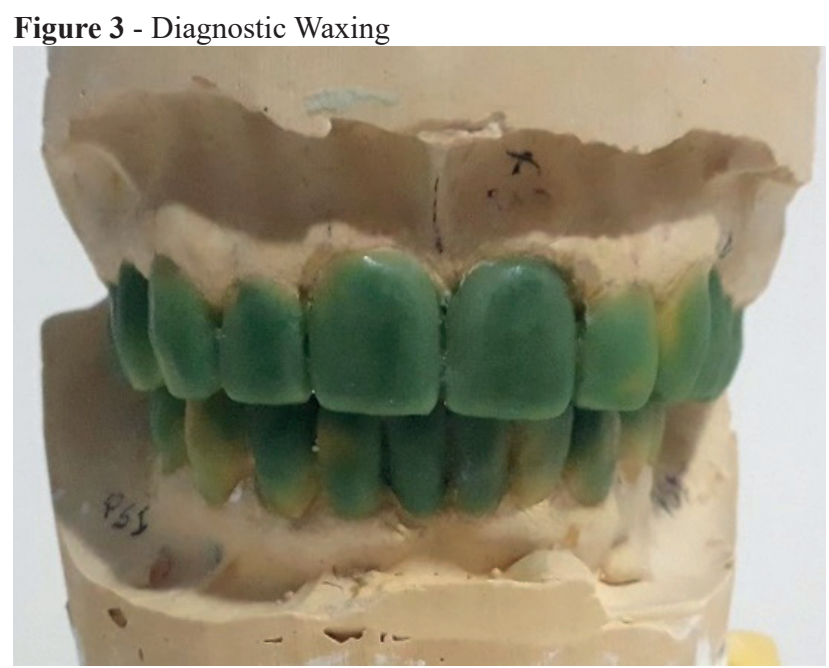

Source: The authors.

The extraction of the element 18 was performed and implants were installed in the region of the elements 14 (Titamax CM 4.0 x 13 mm), 24 (Alvim CM 4.3 x 10 mm), 46 (Titamax CM 3.75 x 9 mm), 36 (Titamax CM 4.0 x $11 \mathrm{~mm}$ ) and 16 (Alvim CM $4.3 \times 13$ ), the latter being after performing the maxillary sinus lifting and graft (Lumina-bone).

Through diagnostic waxing, temporary dental prostheses were made from self-polymerizing acrylic resin (Clássico Artigos Odontológicos - color 61) (Figure 4). Previously, the preparation of the conducts of the element 26 was performed, manufacture and cementing of the molten metal core and preparation of the other elements.

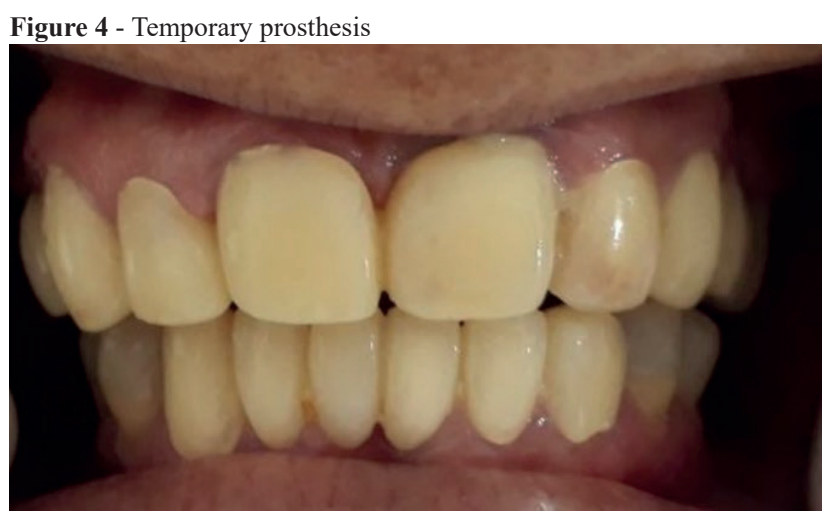

Source: The authors.

In order to conserve the dental structures, from diagnostic waxing a matrix of silicone and restoration of the elements $34,35,44$ and 45 was made with composite resin (Figure 5). 
Figure 5 - Restoration with support of the matrix

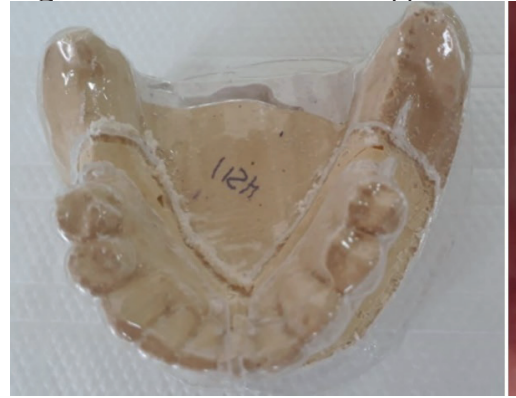

Source: The authors.

Considering that the patient did not have financial conditions for immediate definitive treatment, the preparations were refined and the upper and lower arcades were molded with silicon of Silagum (DMG Chemisch-Pharmazeutische, Hamburg, Germany) of heavy + light viscosity with the use of trays (Figure 6). Then, temporary prosthesis with pressed acrylic resin were obtained (Figure 7).

Figure 6 - making the preparations and molding with caskets
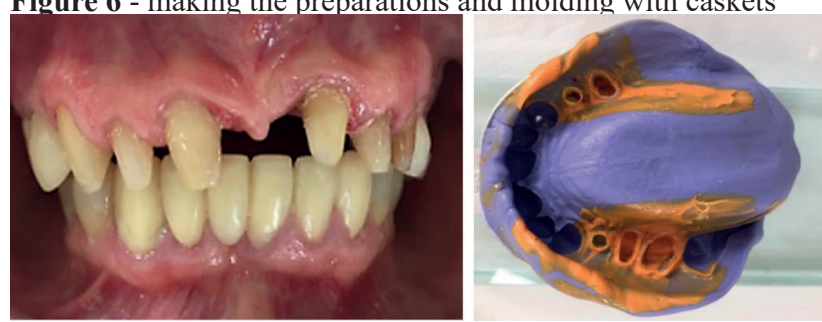

Source: The authors.

\section{Figure 7 - Temporary Pressed Acrylic Dental Prosthesis}

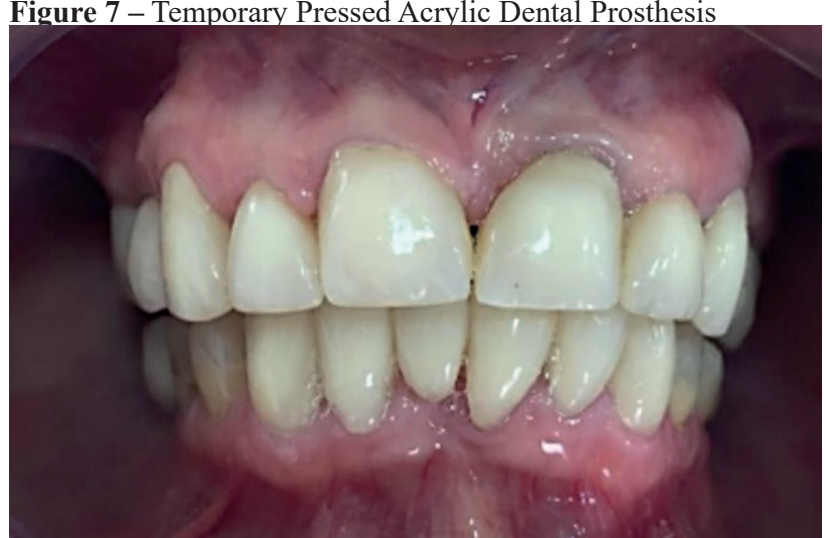

Source: The authors.

The patient was informed that this is a temporary treatment that should be replaced over time and authorized, by signing a statement, the disclosure of the images of her clinical case.

\subsection{Discussion}

The development and improvement of surgical techniques and esthetic restorative materials have contributed to the production of expressive clinical results. In the search for excellence in restoring the beauty of the smile, the surgeondentist has, increasingly, options of techniques and services to offer to his or her patients ${ }^{9,11}$. However, to achieve esthetic excellence, it is not enough to use good materials and techniques, it is necessary to plan properly.
The professional must understand the needs of the patient, listen carefully to his or her expectations and desires, as well as the degree of demand to be able to elaborate the individualized esthetic planning. No treatment will be successful without establishing proper diagnosis and proper planning. This step is probably one of the most important ${ }^{7}$.

In view of this, the present study sought to show, through a case report, the importance of diagnostic waxing in oral rehabilitation, a fundamental tool especially when considering the current philosophy of esthetic excellence, since it allows rehabilitations to be planned and developed in wax guiding clinical and laboratory procedures ${ }^{3}$.

Waxing is performed in a cast model, in which the worn portions of the teeth and/or the missing teeth are rebuilt, determining the interproximal contacts and the occlusal plane desired at the end of the treatment. It therefore helps in the diagnosis and planning of cases of patients with teeth, partially dentated or edentate, in an individualized manner ${ }^{12}$.

It improves communication among the patient, the surgeon-dentist and the technician, representing the outcome of treatment ${ }^{13}$. It is through this communication and threedimensional illustration that the patient acquires confidence and, later, satisfaction with the proposed rehabilitation ${ }^{14,15}$ - Moreover, by predicting the final result, it allows the identification of the need for specific complementary treatments, such as orthodontic interventions. This phase also serves as a guide to tooth preparation as the necessary space can be accurately assessed using silicone matrices ${ }^{16}$.

DW has numerous indications in oral rehabilitation, such as: manufacture of direct restorations, preparation for ceramic facets, making of temporary prostheses and implantodontics ${ }^{17,18}$, all of which are applied in the present case report, except for the facets.

In the case of direct restorations, it is possible by means of diagnostic closure to obtain a preview of extensive cases, reduction and/or closure of diastemas and redefinition of the desired dental anatomy, with the aid of a silicone matrix ${ }^{17}$, as performed in patient elements $34,35,44$ and 45, which with a silicone guide have been restored with composite resin.

Waxing is also useful in the area of the implantodontics, where one of the great concerns of the surgeon-dentist is to obtain a correct implant positioning since poor positioning has as consequences an inadequate gingival contour or shape, sloping teeth, occlusal interferences and closed interproximal spaces. Therefore, the diagnostic phase in which waxing should be performed for the study of the position, length, width and occlusion of the implant to be installed is essential. Next, an impression is made about the waxing and, later, a surgical guide is made. Thus, the surgeon will work with more certainty and predictability ${ }^{9}$.

Simon and Magne ${ }^{13}$ also state that diagnostic waxing can be used in the preparation of the surgical guide used in the installation of implants. When used for this purpose, planning can be performed in an integrated manner, and implant and 
prosthetics can evaluate the case before surgery and plan the positioning of oseointegrated implants and, consequently, of future implants, ensuring the ideal final result. After the waxing and preparation of the provisional teeth, it was possible, in the present clinical case, to establish the correct positioning of the implants that were then installed in the region of the elements 14, 24, 16, 36 and 46.

Any type of prosthetic treatment, whether conventional or on implants, requires the creation of temporary restorations, which facilitate the construction of the permanent prosthesis and, consequently, lead to success. During the use of the transitional prostheses, the contours, texture and occlusal design can be modified until a quality stage is reached capable of fully meeting the biomechanical and esthetic requirements ${ }^{20}$. This type of restoration has the function of providing a patient-friendly esthetic; keeping soft tissues in position and creating an adequate and esthetic emergency profile; it also serves as a template to customize the referrers; restore the proximal contacts; they improve the masticatory function and conserve or recover the vertical dimension of occlusion. It should also provide periodontal and peri-implant health, ease of cleaning, atraumatic margins, as well as good stability, resistance and retention ${ }^{21}$.

The temporary restorations play the role of an architect of the gingival shape and contour and determine the esthetic excellence by the possibility of a harmonious transition from the white esthetics to the pink esthetics. They optimize the anatomy of soft tissues and help to finalize occlusion and esthetics, bringing comfort to the patient and helping in soft tissue healing and creating a better marginal disposition of the $\operatorname{mucosa}^{16,22}$.

In the case of fixed prosthesis, the temporary crown protects the pulp from thermal and chemical injuries after removal of enamel during preparation ${ }^{23}$. Its function is to maintain gingival and contour health, as well as to facilitate esthetic achievement, adequate oral hygiene and maintenance of the occlusal interarchs relationship. For a pleasant esthetic, the crowns must have a good combination of colors and a highly polished surface ${ }^{24}$.

Furthermore, these restorations are useful for diagnostic purposes, where functional and esthetic occlusal parameters are developed to identify the treatment result before the conclusion of definitive procedures ${ }^{25}$. Occasionally, temporary treatment has the need to extend through longer periods of time and during this period should provide protection and stability to the pillar teeth. This situation is usually observed when the execution of the fixed prosthesis is associated with some endodontic, orthodontic, periodontal treatment or the installation of implants ${ }^{26}$.

The temporary prostheses should, therefore, predict the final result, being a prototype and a reference in the planning and construction of the definitive prosthesis ${ }^{20}$. This type of restoration should therefore be similar to definitive prostheses in all aspects, except for the material from which they are manufactured. In this context, diagnostic waxing also plays a key role. In the clinical case presented, this tool enabled the preparation of pressed temporary ones, which provided a better quality of life to the patient offering a satisfactory esthetic, different from the initial aspect in which the tooth conditions and the presence of the diastema prevented the patient from smiling. This temporary tooth will be important for the maintenance of soft tissues and proximal contacts, for the function, and will serve as a reference for the preparation of the definitive treatment, which will be carried out progressively according to the patient's financial conditions.

There are several DW techniques described in the literature. Among them, the progressive waxing technique used in the present case report, in which, with the aid of wax, the sculpture of the lost elements or adjustments in those worn and/or fractured is performed on the study models ${ }^{11}$. Pompeu and Prado ${ }^{12}$ consider that this technique, with added wax, is easy and fast, besides being used, both manually by drip and manual sculpture, and by the use of precast molds that present the same efficiency as conventional diagnostic closure, but without the need to carve out the occlusal surface.

Tarantola and Becker $^{27}$ use the process of waxing with photopolymerizable composite resin. This technique consists of anatomical sculpture with composite resin. Simon and Magne ${ }^{13}$ demonstrated two methods of diagnostic waxing. The first, freehand method, consists of the previous waxing of the restoration and subsequent construction of the restoration in a composite resin directly on the patient, without using adhesive methods, so that the patient is aware of the future restoration. In the other method, known as mock-up waxing, a mold with a silicone matrix is made after waxing, which is filled with composite resin. Despite the different techniques, it is up to the dental surgeon and the dental technician to evaluate what is best for each clinical case, since all of them offer desirable esthetic and functional characteristics at the end of the prosthetic rehabilitation.

With the use of DW, the provisions, shape and adequate esthetics of the teeth are determined from the principles of occlusion and harmony among the mandibular movements, ensuring the prevention of muscular dysfunctions and temporomandibular joint disorders, and consequent stability of the stomatognathic system ${ }^{12,28}$. Thus, this step enabled the achievement of the patient's stomatognathic system harmony.

Dental occlusion presents several positions due to mandibular movements. At the end of oral rehabilitation, it is desirable to achieve occlusal stability, with freedom of mandibular movements and absence of interference in order to obtain a balance of the stomatognathic system and a favorable prognosis . Thus, DW is important to promote dental stability from the restoration of occlusal aspects, such as Spee and Wilson curves, incisive and canine guides, horizontal and vertical trespasses, and the height of the cuspids and the occlusal plane, helping, including, reduction of the time required for occlusal adjustments ${ }^{28}$. 
In addition, DW facilitates communication with the patient and gain of confidence, an important factor in considering that, in the general public's perception, the costs associated with dental treatment are very costly ${ }^{14}$. This fact conditions the decision of the patient regarding the immediate acceptance of the treatment plan, as well as the costs arising from it. Although there is the possibility of the patient having a limited understanding of the restorative options presented to him, this tool becomes a powerful means of communication, essential for increasing acceptance and obtaining the best esthetic result. ${ }^{14}$

Thus, it is possible to affirm that DW should be routine in dental clinical practice for all patients who require oral rehabilitation ${ }^{15}$ although, despite presenting several indications in oral rehabilitation, there are, in the literature, controversies regarding the use of diagnostic closure in relation to cost/benefit.

According to Bidra ${ }^{4}$, the duplication of diagnostic closure is a fast, effective and economical method for the construction of fixed prostheses on implant. However, Dalvit et al. ${ }^{30}$ reported that, although DW is widely used for the diagnosis of patients seeking prosthetic treatment, this technique is not routine in dental practice, because it demands time and does not result in immediate benefits.

In this context, it is emphasized that the mastery of the DW technique by the dental surgeon and the dental technician is of fundamental importance for the decision to use it, because, when correctly indicated, it can help the communication between the clinician and the patient, in addition to contributing to hygiene care, ensuring satisfaction through the functional and esthetic predictability of the rehabilitating treatment.

\section{Conclusion}

Based on what was found in the literature and on the reported clinical case, it can be concluded that DW presents customized solutions offering, by means of a previous study, an effective resolution to the patient. It is also concluded that DW is of fundamental importance for the extensive rehabilitation, complex cases, in the communication with patients anxious for the result and integration among professionals in the area, resulting in a perfect function and esthetics of dental prosthesis and consequent harmony of the stomatognathic system.

\section{References}

1. Koidou VP, Chatzopoulos GS, Rosenstiel SF. Quantification of facial and smile esthetics. J Prosthet Dent 2018;119(2):2707. doi: 10.1016/j.prosdent.2017.04.002.

2. Coachman C, Paravina RD. Digitally enhanced esthetic dentistry: from treatment planning to quality control. J Esthet Restor Dent 2016;1:S3-4. doi: $10.1111 /$ jerd.12205.

3. Garcia PP, da Costa RG, Calgaro M, Ritter AV, Correr GM, da Cunha LF, et al. Digital smile design and mock-up technique for esthetic treatment planning with porcelain laminate veneers. J Conserv Dent 2018;21(4):455-8. doi: 10.4103/
JCD.JCD_172_18.

4. Bidra AS. Chair-side fabrication of a fixed implant-supported prosthesis in an edentulous mandible from a diagnostic waxup: a clinical report. J Oral Implantol 2012;38(3):291-7. doi: 10.1563/AAID-JOI-D-10-00079.

5. Grzić R, Spalj S, Lajnert V, Glavicić S, Uhac I, Pavicić DK. Factors influencing a patient's decision to choose the type of treatment to improve dental esthetics. Vojnosanitetski Pregled 2012;69(11):978-85. doi: 10.2298/VSP111027026G.

6. Abduo J. Geometrical effects of conventional and digital prosthodontic planning wax-ups on lateral occlusal contact number, contact area, and steepness. J Oral Sci 2017;59(3):431-8. doi: 10.2334/josnusd.16-0610.

7. Menezes MS, Carvalho ELA, Silva FP, Reis GR, Borges MG. Reabilitação estética do sorriso com laminados cerâmicos: Relato de caso clínico. Rev Odontol Brasil-Central 2015;24(68):37-43.

8. Gurrea J, Bruguera A. Wax-up and mock-up. A guide for anterior periodontal and restorative treatments. Int J Esthetic Dent 2014;9(2):146-62.

9. Calixto LR, Bandeca MC, Andrade MF. Enceramento diagnóstico: previsibilidade no tratamento estético indireto. Dental Press Estética 2011;3(8):26-37.

10. Pereira DA, Borges MG, Silva FP, Menezes MS. Reabilitação estética do sorriso por meio de procedimento restaurador direto com resina composta nanoparticulada: relato de caso. Rev Odontol Brasil-Central 2016;25(72):54-8.

11. Meirelles L, Bavia PF, Vilanova LSR. Aplicações clínicas do enceramento diagnóstico na reabilitação oral: uma revisão de literatura. Fac Odontol Lins/Unimep 2013;23(1):20-5. doi: 10.15600/2238-1236/fol.v23n1p20-25.

12. Saeidi Pour R, Engler MLPD, Edelhoff D, Prandtner O, Frei S, Liebermann A. A patient-calibrated individual wax-up as an essential tool for planning and creating a patient-oriented treatment concept for pathological tooth wear. Int $\mathrm{J}$ Esthet Dent 2018;13(4):476-92.

13. Simon H, Magne P. Clinically based diagnostic wax-up for optimal esthetics: the diagnostic mock-up. J California Dental Assoc 2008;36(5):355-62.

14. Kahng LS. Patient-dentist-technician communication within the dental team: using a colored treatment plan wax-up. J Esthetic Restorative Dentistr 2006;18(4):185-93. doi: 10.1111/j.1708-8240.2006.00017.x.

15. Carvalho BCF. Utilização de imagem digital para diagnóstico e planejamento estético. Rev Dental Press Estética 2006;3(1):72-82.

16. Sancho-Puchades M., Fehmer V, Hâmmerle C, Sailer I. Advanced smile diagnostics using CAD/CAM mock-ups. Int J Esthet Dent 2015;10(3):374-91. doi: 10.5167/uzh-113473.

17. Miyashita E, Mello AT. Odontologia estética: planejamento e técnica. São Paulo: Artes Médicas; 2011.

18. Dias MLP, Magrin GL, Bez LV, Benfatti CAM, Volpato CAM. Uso de guias no planejamento de próteses sobre implantes. Full Dentistry Scie 2016;7(26):74-82.

19. Kaushal K. Luthra. Implant success!!!... simplified. J Indian Soc Periodontol 2009;13(1):27-9. doi: 10.4103/0972124X.51891.

20. Kadiyala KK, Badisa MK, Anne G, Anche SC, Chiramana $\mathrm{S}$, Muvva SB, et al. Evaluation of flexural strength of thermocycled interim resin materials used in prosthetic 
rehabilitation: an in-vitro study. J Clin Diagn Res 2016;10:915. doi: 10.7860/JCDR/2016/20020.8566.

21. Tahayeri A, Morgan M, Fugolin AP, Bompolaki D, Athirasala A, Pfeifer CS, et al. 3D printed versus conventionally cured provisional crown and bridge dental materials. Dent Mater 2018;34(2):192-200. doi: 10.1016/j. dental.2017.10.003.

22. Palacci P, Nowzari H. Soft tissue enhancement around dental implants. Periodontol 2000 2008;47:113-32. doi: 10.1111/j.1600-0757.2008.00256.x.

23. Seltzer S, Bender IB. The dental pulp-Biologic considerations in dental procedures. J.B. Lippincott 1985;23(5):389. doi:10.1016/0266-4356(85)90020-8.

24. Burke FJ, Murray MC, Shortall AC. Trends in indirect dentistry: Provisional restorations, more than just a temporary. Dent Update 2005;32(8):443-52.

25. Hahnel S, Krifka S, Behr M, Kolbeck C, Lang R, Rosentritt M. Performance of resin materials for temporary fixed denture prostheses. J Oral Sci 2019;61(2):270-5. doi: 10.2334/ josnusd.18-0150.

26. Dayan C, Kiseri B, Gencel B, Kurt H, Tuncer $\mathrm{N}$. Wear resistance and microhardness of various interim fixed prosthesis materials. J Oral Sci 2019;61(3):447-53. doi: 10.2334/josnusd.18-0323.

27. Tarantola GL, Becker IM. Definitive diagnostic waxing with light-cured composite resin. J Prosthetic Dent 1993;70(4):3159. doi: 10.1016/0022-3913(93)90214-9.

28. Koubi S, Gurel G, Margossian P, Massihi R, Tassery H. A simplified approach for restoration of worn dentition using the full mock-up concept: clinical case reports. Int J Periodontics Restorative Dent 2018;38(2):189-97. doi: 10.11607/prd.3186.

29. Peck CC. Biomechanics of occlusion--implications for oral rehabilitation. J Oral Rehabil 2016;43(3):205-14. doi: 10.1111/joor.12345.

30. Dalvit DL, Parker MH, Cameron SM. Quick chairside diagnostic wax-up. J Prosthetic Dent 2002;87(5):581-2. doi: 10.1067/mpr.2002.124491. 